\title{
Systemic lupus erythematosus activity and beta two microglobulin levels
}

\section{Atividade do lúpus eritematoso sistêmico e níveis de beta dois microglobulina}

\author{
Thelma Larocca Skare', Kellen Ferri", Marcela Aimone Santos" \\ Rheumatology Unit, Hospital Universitário Evangélico de Curitiba, Paraná, Brazil
}

'MD, PhD. Associate Professor, Discipline of Rheumatology, Faculdade Evangélica do Paraná, and Head of Rheumatology Unit, Hospital Universitário Evangélico de Curitiba, Curitiba, Paraná, Brazil.

"Medical Student. Faculdade Evangélica do Paraná, Curitiba, Paraná, Brazil.

\section{KEY WORDS:}

Lupus erythematosus, systemic beta 2-microglobulin. Inflammation.

Blood sedimentation.

Acute-phase reaction.

\section{PALAVRAS-CHAVE:}

Lúpus eritematoso sistêmico.

Microglobulina-2 beta.

Inflamação.

Sedimentação sanguínea.

Reação de fase aguda.

\begin{abstract}
CONTEXT AND OBJECTIVE: Systemic lupus erythematosus (SLE) is an autoimmune disease with a cyclical clinical course. Evaluation of the clinical activity of this disease is important for choosing the correct treatment. The objective of this study was to analyze the value of beta-2 microglobulin ( $\beta 2 \mathrm{M}$ ) serum levels in determining SLE clinical activity.

DESIGN AND SETTING: Cross-sectional analytical study conducted at the rheumatology outpatient clinic of a private university hospital.

METHODS: 129 SLE patients were studied regarding disease activity using SLEDAI (SLE Disease Activity Index) and cumulative damage using SLICC ACR (SLE International Collaborating Clinics/American College of Rheumatology Damage Index for SLE). At the same time, the $\beta 2 \mathrm{M}$ serum level, ESR (erythrocyte sedimentation rate), anti-dsDNA (anti-double-stranded DNA) and C3 and C4 complement fractions were determined.

RESULTS: $\beta 2 \mathrm{M}$ levels correlated positively with SLEDAI $(P=0.02)$ and ESR $(P=0.0009)$ and negatively with C3 $(P=0.007)$. Patients who were positive for anti-ds DNA had higher $\beta 2 \mathrm{M}$ serum levels $(P=0.009)$.

CONCLUSION: $\beta 2 \mathrm{M}$ levels are elevated in SLE patients with active disease.
\end{abstract}

\section{RESUMO}

CONTEXTO E OBJETIVO: O lúpus eritematoso sistêmico (LES) é uma doença autoimune com curso clínico flutuante. Determinar a atividade clínica da doença é importante na escolha do tratamento correto. O objetivo deste estudo foi o de analisar se os níveis séricos de beta-2 microglobulina ( $\beta 2 \mathrm{M}$ ) têm valor na determinação da atividade clínica do LES.

TIPO DE ESTUDO E LOCAL: Estudo transversal, analítico, realizado no ambulatório de reumatologia de um hospital universitário particular.

MÉTODOS: 129 pacientes com LES foram estudados para atividade da doença pelo SLEDAI (SLE Disease Activity Index) e para dano cumulativo pelo SLICC (SLE International Collaborating Clinics/American College of Rheumatology Damage Index for SLE). Simultaneamente foram determinados os valores séricos de $\beta 2 \mathrm{M}$, das frações C3 e C4 do complemento, VHS (velocidade de hemossedimentação) e anti dsDNA (DNA de dupla fita).

RESULTADO: Encontrou-se correlação positiva entre níveis de $\beta 2 \mathrm{M}$ com o SLEDAI ( $P=0,02)$, com VHS $(P=0,0009)$ e correlação negativa com níveis de $C 3(P=0,007)$. Pacientes com presença de anti dsDNA tinham níveis mais altos de $\beta 2 \mathrm{M}(\mathrm{P}=0,009)$.

CONCLUSÃO: Níveis de $\beta 2 \mathrm{M}$ estão elevados em pacientes de LES com doença ativa. 


\section{INTRODUCTION}

Systemic lupus erythematosus (SLE) is an autoimmune disease with periods of flares and remissions. ${ }^{1}$ The treatment for SLE accompanies the degree of disease activity and, thus, determining this activity level is very important, even though difficult. Commonly-used inflammatory markers such as sedimentation rate (ESR) and C-reactive protein are nonspecific and unreliable. ${ }^{1}$ On the other hand, composite measurements such as the SLE Disease Activity Index (SLEDAI) and the British Isles Lupus Assessment Group index (BILAG), ${ }^{2}$ which combine laboratory and clinical findings, are time-consuming and not easily applicable in daily practice.

Beta-2 microglobulin $(\beta 2 \mathrm{M})$ is a light-chain subunit of class I human leukocyte antigen (HLA) that exists on the cell membrane of all nucleated cells. ${ }^{3}$ It sheds from the membrane and is measurable in the bloodstream, where its levels are elevated in diseases with high lymphoproliferative activity. ${ }^{3}$ Some authors have noted increased plasma and/or urine $\beta 2 \mathrm{M}$ levels in Sjögren's syndrome, rheumatoid arthritis and SLE, ${ }^{4}$ and have proposed that measuring its levels might be useful as an activity marker.

\section{OBJECTIVE}

The present analysis was undertaken to further examine the relationship between $\beta 2 \mathrm{M}$ and lupus activity, along with the cumulative damage in a sample of Brazilian patients.

\section{METHODS}

This was a cross-sectional analytical study that was approved by the local Research Ethics Committee. All subjects signed an informed consent statement.

We included 129 patients from a single tertiary center, who were all over 18 years of age and met at least four of the classification criteria of the American College of Rheumatology for SLE. ${ }^{5}$ Patients with overlapping features, creatinine above $1.1 \mathrm{mg} / \mathrm{dl}$, previous history of lymphoproliferative disorders, pregnancy or associated infections were excluded. Demographic and clinical data were obtained through chart review.

All individuals underwent measurement of SLEDAI ${ }^{2}$ and SLICC/ACR ${ }^{6}$ (Systemic Lupus Erythematosus International Collaborating Clinics/American College of Rheumatology Damage Index for SLE) along with measurements of $\beta 2 \mathrm{M}, \mathrm{C} 3$, C4, ESR (erythrocyte sedimentation rate), CRP (C-reactive protein), hemoglobin $(\mathrm{Hb})$ levels and anti-dsDNA (anti-doublestranded DNA).

$\beta 2 \mathrm{M}$ measurements were made in serum by means of chemiluminescence (Immulite 2000, Diagnostic Products Corporation, USA), with normal values ranging from 604 to $2786 \mathrm{ng} / \mathrm{ml}$; ESR was measured using the Westergreen method (normal value $<8 \mathrm{~mm}$ ); CRP was measured by means of immunoturbidimetry (normal values $<0.50 \mathrm{mg} / \mathrm{dl}$ ); and $\mathrm{Hb}$ was measured using an automated method (normal values of 12.2-18.1 g/dl). C3 and $\mathrm{C} 4$ were evaluated in fasting serum by means of immunoturbidimetry (normal values for $\mathrm{C} 3=82-170 \mathrm{mg} / \mathrm{dl}$; and for $\mathrm{C} 4=12-36 \mathrm{mg} / \mathrm{dl})$. Anti-dsDNA was analyzed by means of indirect immunofluorescence using Crithidia lucilae as the substrate (Immunoconcept, Alka, São Paulo, Brazil).

The data were compiled in frequency tables. The central trend was expressed as the mean and standard deviation for parametric data and as the median and interquartile range (IQR) for nonparametric data. Correlation analyses were conducted using the Spearman and Pearson tests, according to sample distribution. An association analysis on $\beta 2 \mathrm{M}$ levels in the presence of antidsDNA was done using the Mann-Whitney test. The GraphPad Prism software, version 4.0, was used for calculations. The significance level was taken to be $5 \%$.

\section{RESULTS}

In this sample, $3.1 \%$ were male and $96.9 \%$ were female, with a mean age of $40.1 \pm 11.3$ years and median disease duration of 8.0 years. Regarding the cumulative clinical profile: $67.1 \%$ patients had photosensitivity; $60.1 \%$ arthritis; $43.3 \%$ oral ulcers; $39.8 \%$ butterfly rash; 36.3\% glomerulonephritis; $32.1 \%$ leucopenia; $9.0 \%$ pericarditis; $8.3 \%$ hemolytic anemia; $8.3 \%$ seizures; $6.9 \%$ discoid lesions; $5.5 \%$ pleuritis; $6.2 \%$ thrombocytopenia; and $3.4 \%$ psychosis.

In this population, $54.4 \%$ were using glucocorticoids; $71.2 \%$ antimalarials; $17.8 \%$ azathioprine; $15.8 \%$ methotrexate; $5.9 \%$ mycophenolate mofetil; $1.9 \%$ cyclophosphamide; $0.9 \%$ cyclosporine and $0.9 \%$ thalidomide.

SLEDAI ranged from 0 to 14 (median 0.0 ; IQR $=0.0-2.0$ ); and SLICC ranged from 0 to 9 (median $=1.0 ; \mathrm{IQR}=0.0-2.0)$. The median ESR was $25.0 \mathrm{~mm}(\mathrm{IQR}=9.0-44.5 \mathrm{~mm})$; the median C3 level was $111.0 \mathrm{mg} / \mathrm{dl}(\mathrm{IQR}=92.8-131.1 \mathrm{mg} / \mathrm{dl})$ and median C4, $19.0 \mathrm{mg} / \mathrm{dl}(\mathrm{IQR}=13.8-23.7 \mathrm{mg} / \mathrm{dl})$. The median $\mathrm{Hb}$ level was $13.0 \mathrm{~g} / \mathrm{dl}(\mathrm{IQR}=12.3-14.0)$ and median CRP was $2.6 \mathrm{mg} / \mathrm{dl}$.

In $28.6 \%$ of the patients, anti-dsDNA was positive; $\beta 2 \mathrm{M}$ ranged from 1120 to $4943 \mathrm{ng} / \mathrm{ml}$ (median of $2045 \mathrm{ng} / \mathrm{ml}$; IQR from $1679-2591 \mathrm{ng} / \mathrm{ml}$ ). The correlations of $\beta 2 \mathrm{M}$ with SLEDAI, SLICC, complement, hemoglobin, C-reactive protein and ESR can be seen in Table 1. The median value for $\beta 2 \mathrm{M}$ in patients with positive anti-dsDNA was $2167 \mathrm{ng} / \mathrm{ml}$ (1829-3003 ng/ml), while in those without anti-dsDNA the median was $1950 \mathrm{ng} / \mathrm{ml}$ (1600-2307 ng/ml; P = 0.009).

The correlation of SLEDAI with $\mathrm{C} 3$ showed $\mathrm{P}=0.01$ $(\mathrm{R}=-0.21 ; 95 \%$ confidence interval, $\mathrm{CI}=-0.37$ to -0.03$)$; with $\mathrm{ESR}, \mathrm{P}=0.04(\mathrm{R}=0.17 ; 95 \% \mathrm{CI}=0.001$ to 0.34$)$; and with $\mathrm{CRP}$, $\mathrm{P}=0.28(\mathrm{R}=0.09 ; 95 \% \mathrm{CI}=-0.08$ to 0.26$)$. Patients with antidsDNA had a median SLEDAI of 4.0, while those without it had a median value of $1.0(\mathrm{P}=0.01)$. 


\section{DISCUSSION}

$\beta 2 \mathrm{M}$ is a small protein that has an amino acid sequence related to the constant parts of heavy and light chains of immunoglobulins. ${ }^{7}$ It locates on the surface of all nucleated cells and its bestcharacterized function is to interact with and stabilize the tertiary structure of the $\mathrm{MHC}$ class 1 chain. ${ }^{7} \beta 2 \mathrm{M}$ is normally found in serum, urine and other body fluids and is almost exclusively catabolized within the kidney; $95 \%$ to $100 \%$ of circulating $\beta 2 \mathrm{M}$ is eliminated through glomerular filtration. ${ }^{7}$

The reason why it has been found to be elevated in SLE patients is unknown. Some authors ${ }^{4}$ believed that this might result from the increased turnover of lymphocytes seen in this disease. Autoantibodies directed against $\beta 2 \mathrm{M}$ that present lymphocytotoxic activity have also been reported in SLE. ${ }^{8}$ Since immune complexes formed by $\beta 2 \mathrm{M}$ and anti- $\beta 2 \mathrm{M}$ have a larger size, they cannot be filtered by the kidney, thus raising the serum levels of $\beta 2 \mathrm{M}$ and giving another explanation for this elevation.

Walters et al. ${ }^{9}$ detected higher levels of serum $\beta 2 \mathrm{M}$ in rheumatoid arthritis patients and an even higher concentration in synovial fluids, which suggested that there is intra-articular production of this protein in this disease. Interestingly, in studying the possible associations between $\beta 2 \mathrm{M}$ and specific lupus manifestations, Kim et al. ${ }^{4}$ found that the serum levels were higher in patients with serositis, oral ulcers and glomerulonephritis but not in those with arthritis. Experimental studies ${ }^{10}$ on $\beta 2 \mathrm{M}$-deficient lupus mice showed that a lack of $\beta 2 \mathrm{M}$ caused dissociation in the clinical expression of the disease, with aggravation of skin disease and amelioration of nephritis. This divergence of disease in the skin and kidneys of $\beta 2 \mathrm{M}$-deficient mice suggests that target organs may respond in different ways to the autoimmune process in this context.

Another study on 26 lupus patients, by Hermansen et al., ${ }^{11}$ found that serum $\beta 2 \mathrm{M}$ showed correlations with cytokines such as interleukin (IL)-6, IL-8, IL-10 and IL-18, and with serum interferon- $\alpha$. These authors believed that the increased $\beta 2 \mathrm{M} \mathrm{lev-}$ els in active SLE reflected the overall immunological activity.

In the present study, we found that ESR, CRP, C3 and SLEDAI were associated with $\beta 2 \mathrm{M}$, thus showing that its level was elevated in cases of active disease. This result is similar to the findings of Evrin and Ström ${ }^{8}$ in 23 Swedish lupus patients, in whom they found a positive correlation with ESR and a negative association with hemoglobin levels. Moreover, Kim et al. ${ }^{4}$ studying Korean lupus population found a negative correlation between $\beta 2 \mathrm{M}$ and $\mathrm{C} 3$ and a positive correlation between $\beta 2 \mathrm{M}$ and SLEDAI, as we did. In a disease such as SLE, with great influence of genetic background, our results showed that the levels of $\beta 2 \mathrm{M}$ in lupus activity in a sample of Brazilian population follow the same pattern as others. Furthermore, we did not find any association of $\beta 2 \mathrm{M}$ with SLE cumulative damage measured by SLICC/ACR, which had not been studied previously.
Table 1. Result from correlating $\beta 2$ microglobulin levels with the Systemic Lupus International Collaborating Clinics/American College of Rheumatology (SLICC/ACR) index, systemic lupus erythematosus disease activity index (SLEDAI), complement, hemoglobin, C-reactive protein and sedimentation rate

\begin{tabular}{lccc} 
& $\mathbf{R}$ & $\mathbf{9 5 \%}$ confidence interval & $\mathbf{P}$ \\
SLICC/ACR & -0.05 & -0.23 to 0.12 & 0.50 \\
SLEDAl & 0.20 & 0.02 to 0.36 & 0.02 \\
C3 $(\mathrm{mg} / \mathrm{dl})$ & -0.23 & -0.39 to -0.05 & 0.007 \\
C4 $(\mathrm{mg} / \mathrm{dl})$ & -0.12 & -0.29 to 0.05 & 0.17 \\
Sedimentation rate $(\mathrm{mm})$ & 0.28 & 0.11 to 0.44 & 0.0009 \\
Hemoglobin $(\mathrm{g} / \mathrm{dl})$ & -0.26 & -0.42 to -0.09 & 0.002 \\
C-reactive protein & 0.21 & 0.03 to 0.37 & 0.014 \\
\hline
\end{tabular}

We also showed that, in this sample, SLEDAI correlated with ESR, C3 and anti-dsDNA, which raises the question of the additional value in measuring $\beta 2 \mathrm{M}$. It needs to be noted that in this study we excluded patients with associated infections, which are a cause of great confusion in ESR interpretation. Also, C3 consumption and presence of anti-dsDNA are associated with specific lupus manifestations. Membranous glomerulonephritis (or class 5 glomerulonephritis) is a typical example in which the lupus manifestation may appear with a normal complement and without anti-dsDNA. ${ }^{12,13}$ In these situations, assaying for $\beta 2 \mathrm{M}$ may help to determine disease activity.

\section{CONCLUSIONS}

Our findings provide confirmation that $\beta 2 \mathrm{M}$ levels are elevated in cases of active lupus, which thus may help in determining the degree of disease activity. Further studies are needed in order to understand the role of this protein in the pathophysiological process of lupus.

\section{REFERENCES}

1. Suh $\mathrm{CH}$, Jeing $\mathrm{YS}$, Park $\mathrm{HC}$, et al. Risk factors for infection and role of C-reactive protein in Korean patients with systemic lupus erythematosus. Clin Exp Rheumatol. 2001;19(2):191-4.

2. Liang MH, Socher SA, Larson MG, Schur PH. Reliability and validity of six systems for clinical assessment of disease activity on systemic lupus erythematosus. Arthritis Rheum. 1989;32(9):1107-18.

3. McPhee CG, Sproule TJ, Shin DM, et al. MHC class I family proteins retard systemic lupus erythematosus autoimmunity and B cell lymphomagenesis. J Immunol. 2011;187(9):4695-704.

4. Kim HA, Jeon JY, Yoon JM, Suh CH. Beta 2-microglobulin can be a disease activity marker in systemic lupus erythematosus. Am J Med Sci. 2010;339(4):337-40.

5. Tan EM, Cohen AS, Fries JF, et al. The 1982 revised criteria for the classification of systemic lupus erythematosus. Arthritis Rheum. 1982;25(11):1271-7

6. Stoll T, Seifert B, Isenberg DA. SLICC/ACR Damage Index is valid, and renal and pulmonary organ scores are predictors of severe outcome in patients with systemic lupus erythematosus. Br J Rheumatol. 1996;35(3):248-54 
7. Xie J, Wang Y, Freeman ME 3rd, Barlogie B, Yi Q. Beta 2-microglobulin as a negative regulator of the immune system: high concentrations of the protein inhibit in vitro generation of functional dendritic cells. Blood. 2003;101(10):4005-12.

8. Evrin PE, Ström T. Beta 2-microglobulin and its binding activity in serum from patients with SLE. Ann Rheum Dis. 1984;43(2):267-74.

9. Walters MT, Stevenson FK, Goswami R, Smith JL, Cawley MI. Comparison of serum and synovial fluid concentrations of beta 2-microglobulin and $C$ reactive protein in relation to clinical disease activity and synovial inflammation in rheumatoid arthritis. Ann Rheum Dis. 1989:48(11):905-11.

10. Chan OT, Paliwal V, McNiff JM, et al. Deficiency in beta(2)-microglobulin, but not CD1, accelerates spontaneous lupus skin disease while inhibiting nephritis in MRL-Fas(lpr) mice: an example of disease regulation at the organ level. J Immunol. 2001;167(5):2985-90.

11. Hermansen ML, Hummelshøj L, Lundsgaard D, et al. Increased serum $\beta 2$-microglobulin is associated with clinical and immunological markers of disease activity in systemic lupus erythematosus patients. Lupus. 2012;21(10):1098-104.

12. Falk RJ, Schur PH, Appel GB. Clinical features and therapy of membranous lupus nephritis. Uptodate.com. Available from: http:// www.uptodate.com/contents/clinical-features-and-therapy-ofmembranous-lupus-nephritis. Accessed in 2013 (Sep 4).

13. Sun $\mathrm{HO}$, Hu WX, Xie HL, et al. Long-term outcome of Chinese patients with membranous lupus nephropathy. Lupus. 2008;17(1):56-61.

Marcela Aimone Santos is a grantee of Programa Institucional de Bolsas de Iniciação Científica - Conselho Nacional de Desenvolvimento Científico e Tecnológico (PIBIC-CNPq), Brazil

Sources of funding: None

Conflict of interest: None

Date of first submission: April 17, 2013

Last received: September 11, 2013

Accepted: September 17, 2013

\section{Address for correspondence:}

Thelma Larocca Skare

Rua João Alencar Guimaraes, 796

Santa Quitéria — Curitiba (PR) — Brasil

CEP 80310-420

Tel. (+55 41) 3274-1659

E-mail: tskare@onda.com.br 